\title{
Optimasi Tablet Lepas Cepat Levofloksasin Hidroklorida Menggunakan Crospovidone Sebagai Disintegran dan Studi Disolusi Efisiensi
}

\author{
Immediate Release Tablet of Levofloxacin Hydrocloride Using Crospovidone \\ as Disintegrant: Optimazation and Dissolution Efficiency Study
}

\author{
Puspa Dwi Pratiwi, Akhmad Kharis Nugroho*, Endang Lukitaningsih \\ Fakultas Farmasi Universitas Gadjah Mada \\ Corresponding author: Akhmad Kharis Nugroho: Email: a.k.nugroho@ugm.ac.id \\ Submitted: 30-07-2019 Revised: 20-08-2019 Accepted: 11-09-2019
}

\begin{abstract}
ABSTRAK
Tablet mengandung zat aktif dan eksipien yang berfungsi untuk meningkatkan sifat fisik tablet sehingga perlunya optimasi dan pengaruhnya terhadap sifat fisik tablet. Crospovidone merupakan salah satu disintegran yang diklaim dapat meningkatkan waktu hancur dan disolusi obat. Tujuan dari penelitian ini adalah melakukan optimasi tablet dan menentukan efek dari perbedaan jumlah crospovidone terhadap respon untuk mendapatkan formula optimal. Optimasi tablet dilakukan metode simplex lattice design dari perangkat lunak Design Expert versi 11 menggunakan dua variabel independen, yaitu crospovidone 2-10\% dan laktosa monohidrat (45-53\%). Preparasi tablet dilakukan menggunakan metode granulasi basah. Semua formula dilakukan uji sifat alir serbuk, kekerasan tablet, kerapuhan tablet, waktu hancur tablet, penentuan kadar levofloksasin dalam tablet, dan DE60. Formula optimal didapatkan dari respon kekerasan tablet, kerapuhan tablet, waktu hancur tablet, dan DE60. Formula optimal yang didapatkan adalah formula dengan jumlah crosspovidone 10\% ditandai dengan nilai desirability 0,546 menghasilkan sifat fisik tablet berupa rata-rata kekerasan 4,33 kg, kerapuhan 0,49\%, waktu hancur 6,36 menit, dan rata rata DE60 sebesar 75,00\%. Terdapat perbedaan signifikan adanya perbedaan jumlah crospovidone terhadap waktu hancur. Tidak terdapat perbedaan signifikan antara respon prediksi yang diberikan perangkat lunak Design Expert versi 11 dengan hasil observasi sehingga simplex lattice design dari perangkat lunak Design Expert versi 11 mampu memprediksi respon secara akurat.
\end{abstract}

Kata kunci: tablet; levofloksasin; crospovidone

\begin{abstract}
Tablet is solid dosage form which mainly used for oral route that has active substance and exipients to help it gets maximum physical properties, dissolution time and drug dissolve. It is necessary to optimize the number of excipients with design of experimental software. The aims of this study was to optimaze tablet formulation and determine the effect of the difference amount of crospovidone on the response i.e hardness, disintegration time, friability, and dissolution efficiency 60 minnutes (DE60). Simplex lattice design was used for optimize with two independent variable i.e crospovidone (2-10\%) and lactose monohydrate(45-53\%). Tablet preparation used wet granulation method and consider the physical properties and dissolution efficiency to get the optimal formula. Optimal formula were found with desirability value 0546 with hardness 4.33 , friablity $0.49 \%$, disintegration time 6.36 minutes, and $\mathrm{DE}_{60}$ 75.00\%. there was significant difference of disintegration time due to the difference of crospovidone quantity, but the difference of crospovidone was no affect on hardness, friability, and $\mathrm{DE}_{60}$ tablet. The optimal formula has $10 \%$ of crospovidone. There was no significant difference of prediction responses with observation respons. This shows that the design expert software is able to show the results of the response of levofloxacin tablet with the crosspovidone disintegration correctly.
\end{abstract}

Keywords: tablet; levofloxacin; crospovidone 


\section{PENDAHULUAN}

Oral merupakan salah satu cara pemberian obat yang paling banyak dipilih dikarenakan kemudahan dalam pemberian obat kepada pasien dan tidak timbul rasa sakit ketika diberikan kepada pasien. Tablet merupakan salah satu bentuk sediaan obat yang dapat diberikan secara oral. Sebagian besar zat aktif dapat diformulasikan kedalam bentuk sediaan tablet. Tablet merupakan bentuk sediaan padat yang biasanya terdiri dari zat aktif dan bahan tambahan lain yang memiliki fungsi untuk meningkatkan sifat fisik tablet dan berperan dalam tahap awal proses absorpsi (Sastry et al., 2000; Thakkar and Desai, 2015).

Crospovidone merupakan salah satu bahan tambahan obat yang digunakan untk proses inisiasi dan mempercepat hancurnya tablet menjadi partikel yang lebih kecil. Crospovidone merupakan superdisintegran, yaitu memiliki kemampuan lebih dari disintegran lainnya dalam mempercepat proses hancurnya tablet. Meningkatnya waktu hancur tablet dapat mempercepat waktu dan jumlah obat yang terdisolusi sehingga dapat meningkatkan konsentrasi obat dalam darah. Partikel berpori dari crospovidone menyebabkan timbulnya gaya kapilaritas yang menarik air ke dalam tablet. Hal tersebut menyebabkan tablet menjadi mengembang dan hancur (Gerber et al., 2018; Mohanachandran et al., 2011; Pabari and Ramtoola, 2012).

Untuk mendapatkan sifat tablet yang maksimal, diperlukannya optimasi jumlah bahan tambahan yang digunakan dalam pembuatan tablet. optimasi tersebut dapat dilakukan sebelum penelitian yang dilakukan dengan salah satu perangkat lunak desain eksperimental yaitu design expert versi 10 . Simplex lattice design merupakan metode yang dipilih pada penelitian ini metode untuk mendapatkan formula optimal dari sejumlah variabel dengan konsentrasi yang berubah secara simultan dan dengan menjaga agar bobot akhir sediaan adalah tetap (Politis et al., 2017).

Levofloksasin merupakan salah satu antibiotik spektrum luas golongan flouroquinolin yang efeknya tergantung dari konsentrasi. Semakin besar konsentrasi dalam plasma, maka kemampuan antibiotik dalam membunuh bakteri akan semakin besar pula. Hal tersebut menjadi salah satu pertimbangan levofloksasin diformulasikan sebagai tablet lepas cepat dengan superdisintegran, yaitu untuk mempercepat waktu disolusi dan jumlah obat yang terdisolusi dibandingkan dengan disintegran biasa. Adanya peningkatan waktu dan jumlah obat yang terdisolusi diharapkan dapat meningkatkan bioavailabilitas obat (Gerber et al., 2018; Noel, 2009).

Tujuan dari penelitian ini adalah optimasi menggunakan metode simplex lattice design dari tablet levofloxacin hidroklorida dengan crospovidone sebagai disintegran. Rekomendasi formula dengan perbedaan jumlah crospovidone dilakukan evaluasi sifat fisik dan uji disolusi in vitro untuk mendapatkan persen disolusi efisiensi. Dari respon tersebut akan didapatkan formula optimal yang akan dilakukan uji verifikasi.

\section{METODOLOGI \\ Bahan}

Levofloksasin hidroklorida dibeli dari PT Kimia Farma Tbk; crospovidone, magnesium stearat, dan PVPK30 dibeli dari Asian Chemical; laktosa monohidrat dan talkum dibeli dari Bratachem, Yogyakarta.

\section{Alat}

Disintegration tester (Erweka Z.T.21), friability tester (Erweka), hardness tester (Stoke Mosanto ${ }^{\circledR}$ ), mesin cetak tablet (single punch merk Korsch $®$ ), neraca analitik (Mettler Toledo®), dissolution tester (Erweka DT-700®), dan spektrofotometer (Hitachi® U-2810)

\section{Jalannya Penelitian}

Optimasi Formula Tablet Levofloksasin

Batas minimal jumlah disintegran yang digunakan dalam formula adalah $2 \%(\mathrm{~b} / \mathrm{b})$ dan batas maksimal adalah $10 \%$ (b/b) sedangkan unuk bahan pengisi, batas minimal adalah $44 \%$ hingga $52 \%$ dari bobot tablet dengan jumlah kedua variabel tersebut adalah $82 \mathrm{mg}$. Bahan pengikat, lubrikan, dan glidan dibuat konstan dan menghasilkan bobot tablet levofloksasin untuk setiap formula yaitu sebesar $150 \mathrm{mg}$. Formula yang diperoleh tersaji pada tabel I.

Pembuatan tablet levofloksasin

Tablet levofloksasin dibuat dengan menggunakan metode granulasi basah. Sejumlah levofloksasin, laktosa, dan crospovidone dari formula dicampur hingga homogen sebagai fase internal tablet. Sebanyak 5 mL larutan PVP K30 2\% (untuk 200 tablet levofloksasin) ditambahkan sedikit demi sedikit. Campuran tersebut diaduk hingga 
Tabel I. Formula tablet levofloksasin

\begin{tabular}{lcccccccc}
\hline Bahan & Run 1 & Run 2 & Run 3 & Run 4 & Run 5 & Run 6 & Run 7 & Run 8 \\
\hline Levofloksasin (mg) & 60 & 60 & 60 & 60 & 60 & 60 & 60 & 60 \\
laktosa (mg) & 70 & 76 & 73 & 79 & 67 & 79 & 73 & 67 \\
PVPK30 (mg) & 0,5 & 0,5 & 0,5 & 0,5 & 0,5 & 0,5 & 0,5 & 0,5 \\
Crospovidone (mg) & 12 & 6 & 9 & 3 & 15 & 3 & 9 & 15 \\
Talkum (mg) & 6,75 & 6,75 & 6,75 & 6,75 & 6,75 & 6,75 & 6,75 & 6,75 \\
Mg. Stearat (mg) & 0,75 & 0,75 & 0,75 & 0,75 & 0,75 & 0,75 & 0,75 & 0,75 \\
\hline
\end{tabular}

mendapatkan konsistensi massa yang elastis. Massa yang diperoleh dilakukan pengayakan menggunakan ayakan ukuran mesh 16 kemudian dikeringkan dalam oven pada suhu $45^{\circ} \mathrm{C}$ selama 12 jam. Massa hasil pengeringan diayak dengan ayakan mesh 20. Granul hasil pengayakan dicampurkan dengan fase eksternal yang terdiri dari sebagian talkum, dan magnesium stearat. Campuran tersebut kemudian dikempa dengan mesin cetak single punch dengan diameter punch $5 \mathrm{~mm}$.

Kecepatan alir

Serbuk dengan berat 50 gram ditimbang kemudian dimasukkan ke dalam corong uji waktu alir. Tutup corong dibuka dan dicatat waktu yang diperlukan granul keluar dari corong (United States Pharmacopeial, 2009).

\section{Keragaman bobot}

Sebanyak 10 tablet ditimbang satu per satu, dihitung jumlah persen zat aktif dalam tiap tablet dari jumlah yang tertera pada etiket dari hasil penetapan kadar masing-masing tablet kemudian dihitung nilai penerimaan. Nilai penerimaan maksimal yang diperbolehkan untuk 10 tablet adalah 15\% (Departemen Kesehatan Republik Indonesia, 2014).

\section{Kekerasan Tablet}

Sebanyak 6 tablet diambil secara acak untuk dilakukan uji kekerasan dengan menggunakan hardness tester (Stoke Mosanto®). Nilai rata-rata kekerasan 6 tablet dihitung beserta nilai standar deviasinya.

Kerapuhan tablet

Sebanyak 20 tablet dibersihkan dan ditimbang bobotnya. Seluruh tablet dimasukan ke friability tester dan alat uji dijalankan dengan jumlah rotasi sebanyak 100 kali. Setelah selesai tablet dibersihkan dari debu dan ditimbang. Nilai kerapuhan tablet diperoleh dari perhitungan dengan menggunakan persamaan sebagai berikut:

$$
\begin{aligned}
& \text { Kerapuhan } \\
& =\frac{\text { (bobot sebelum }- \text { bobot setelah) }}{\text { bobot sebelum }} \times 100 \%
\end{aligned}
$$

Waktu hancur

Sebanyak enam tablet dimasukan kedalam keranjang alat disintegration tester. Media yang digunakan berupa air dengan suhu $37 \pm 0,5^{\circ} \mathrm{C}$. Waktu hancur tablet dihitung mulai saat keranjang masuk ke medium sampai semua tablet hancur sempurna. Alat dijalankan hingga 15 menit. Tablet levofloksasin memenuhi persyaratan waktu hancur jika enam tablet hancur sempurna dalam waktu 15 menit.

Penentuan kadar levofloksasin dalam tablet Metode yang digunakan telah dilakukan validasi dengan spektrofotometer UV-Vis. Sebanyak 10 tablet digunakan untuk uji penentuan kadar. Masing-masing tablet ditimbang kemudian dilarutkan menggunakan 0,1 N HCl dalam labu 25 mL. Larutan kemudian disaring dengan menggunakan kertas saring Whatman ukuran 42. Dari larutan tersebut diambil sebanyak $25 \mu \mathrm{L}$ kemudian ditambahkan $0,1 \mathrm{~N} \mathrm{HCl}$ hingga volume $25 \mathrm{~mL}$ (pengenceran 1000 kali). Sampel ditentukan absorbansinya menggunakan spektrofotometer UV-Vis pada panjang gelombang maksimal (295 nm) (Desai et al., 2011).

Disolusi efisiensi hingga menit ke-60 (DE60)

Uji disolusi menggunakan metode pengaduk tipe dayung ( $p a d d l e$ ) dengan medium $900 \mathrm{ml}( \pm 1 \%) 0,1 \mathrm{~N} \mathrm{HCl}$. Suhu dijaga pada $37 \pm 0,5^{\circ} \mathrm{C}$ dengan kecepatan perputaran dayung adalah $100 \mathrm{rpm}$. Sampel larutan diambil setelah $10,20,30,40,50$, dan 60 menit. Sebanyak $5 \mathrm{ml}$ medium diambil dan diganti dengan medium baru dengan jumlah yang sama. Sampel kemudian dianalisis dengan spektrofotometer 
Tabel II. Sifat alir serbuk dan sifat fisik tablet levofloksasin

\begin{tabular}{|c|c|c|c|c|c|c|c|}
\hline Run & $\begin{array}{c}\text { Kecepatan } \\
\text { alir serbuk } \\
\text { (g/detik) }\end{array}$ & $\begin{array}{c}\text { NP } \\
\text { Keragaman } \\
\text { bobot (\%) }\end{array}$ & $\begin{array}{c}\text { Kekerasan } \\
\text { (kg) }\end{array}$ & $\begin{array}{c}\text { Waktu } \\
\text { hancur } \\
\text { (menit) }\end{array}$ & $\begin{array}{c}\text { Kerapuhan } \\
\text { (\%) }\end{array}$ & $\begin{array}{c}\text { Kadar } \\
(\%)\end{array}$ & $\begin{array}{l}\text { DE}_{60} \\
\text { (\%) }\end{array}$ \\
\hline 1 & 61.73 & 1,78 & 4,4 & 6,34 & 0,33 & $\begin{array}{c}97.87 \pm \\
4.29\end{array}$ & $\begin{array}{r}74,15 \\
\pm 2,56\end{array}$ \\
\hline 2 & 56.18 & 1,97 & 5,23 & 7,38 & 0,33 & $\begin{array}{c}98.93 \pm \\
4.60\end{array}$ & $\begin{array}{r}72,26 \\
\pm 2,76\end{array}$ \\
\hline 3 & 61.73 & 1,65 & 4,4 & 7,24 & 0,67 & $\begin{array}{c}98.57 \pm \\
6.64\end{array}$ & $\begin{array}{r}72,68 \\
\pm 5,11\end{array}$ \\
\hline 4 & 68.50 & 1,79 & 3,83 & 8,14 & 0,67 & $\begin{array}{c}96.81 \pm \\
4.33\end{array}$ & $\begin{array}{r}67,78 \\
\pm 3,76\end{array}$ \\
\hline 5 & 60.98 & 1,78 & 4,68 & 6,22 & 0,34 & $\begin{array}{c}101.06 \pm \\
7.04\end{array}$ & $\begin{array}{r}70,90 \\
\pm 0,60\end{array}$ \\
\hline 6 & 56.19 & 4,58 & 7,1 & 8,08 & 0,06 & $\begin{array}{c}97.47 \pm \\
4.06\end{array}$ & $\begin{array}{r}79,38 \\
\pm 1,27\end{array}$ \\
\hline 7 & 61.73 & 1,97 & 4,5 & 7,28 & 0,37 & $\begin{array}{c}99.42 \pm \\
5.13\end{array}$ & $\begin{array}{r}73,58 \\
\pm 2,47\end{array}$ \\
\hline 8 & 89.29 & 2,04 & 3,5 & 7,04 & 0,61 & $\begin{array}{c}100.59 \pm \\
3.55\end{array}$ & $\begin{array}{r}70,99 \\
\pm 1,20 \\
\end{array}$ \\
\hline
\end{tabular}

UV-Vis pada panjang gelombang maksimal $(295$ $\mathrm{nm})$. Disolusi efisiensi dihitung dengan menggunakan persamaan berikut (Khan, 1975).

$$
\mathrm{DE}_{\mathrm{t}}=\frac{\int_{0}^{t} y \cdot d t}{y_{100 \cdot t}} \times 100 \%
$$

Keterangan: $\mathrm{DE}_{\mathrm{t}}=$ disolusi efisiensi hingga waktu ke-t; $\int_{0}^{t} y \cdot d t=$ luas daerah dibawah kurva dari waktu ke-0 hingga ke-t; $y_{100} \cdot t=$ Luas segi empat $100 \%$ hingga waktu ke-t.

\section{HASIL DAN PEMBAHASAN}

Berdasarkan pengujian kecepatan alir, diperoleh hasil kecepatan alir yang bagus yaitu memiliki kecepatan diatas 10g/detik. Penentuan sifat alir sangat penting dikarenakan dapat mempengaruhi keseragaman bobot, kekerasan dan kadar zat aktif dalam sediaan. Parameter keragaman bobot juga telah memenuhi persyaratan Farmakope Indonesia Edisi $\mathrm{V}$ dengan nilai penerimaan kurang dari $15 \%$ untuk 10 tablet yaitu berada pada rentang nilai penerimaan (NP) antara 1,65-4,58\%. Selain itu, tablet yang dihasilkan memiliki rentang kadar 97-101\%. Rentang tersebut juga telah memenuhi persyaratan kompendian yaitu kadar levofloksasin dalam tablet berada pada rentang 90-110\%. Hasil pengujian sifat alir serbuk dan sifat fisik tablet levofloksasin tersaji pada tabel II.
Kekerasaan tablet

Hasil analisis uji kekerasan memiliki $p$ value model sebesar 0,1932 (tidak signifikan) yang memiliki makna bahwa formula yang direkomendasikan oleh perangkat lunak, yaitu adanya perbedaan jumlah crospovidone antar formula, tidak memiliki pengaruh signifikan terhadap nilai kekerasan observasi. Tablet memiliki kekerasan yang baik apabila hasil pengujian menunjukkan nilai antara 4-8 kg. Namun terkadang kekerasan tablet yang tidak termasuk dalam rentang nilai tersebut masih dapat diterima apabila memenuhi syarat kerapuhan tablet, waktu hancur hingga disolusi.

\section{Kerapuhan tablet}

Dari hasil tersebut, nilai kerapuhan semua formulasi sudah berada dibawah $1 \%$ dan telah memenuhi persyaratan kompendial (ICH, 2017). Dari hasil tersebut juga dapat disimpulkan bahwa tidak terdapat perbedaan nilai kerapuhan dengan adanya variasi jumlah crospovidone pada tablet levofloksasin karena hasil menunjukkan nilai kerapuhan tablet yang hampir sama pada tiap formula yang dibuktikan dengan nilai $p$-value model dari Design Expert, memberikan nilai yang tidak signifikan sebesar 0,6614 $(>0,05)$. 


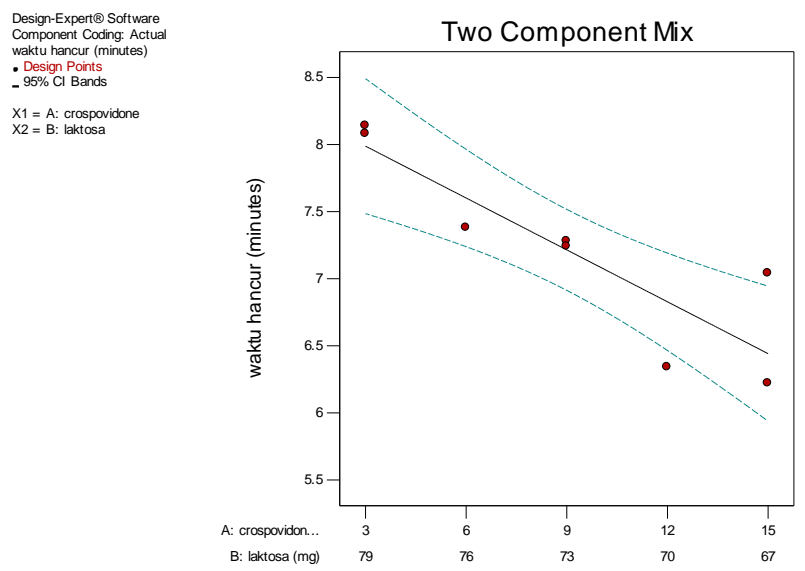

Gambar 1. Contour plot waktu hancur

Tabel III. Komponen respon yang dioptimasi dan target respon

\begin{tabular}{lccc}
\hline Respon & Target & Batas minimal & Batas maksimal \\
\hline Crospovidone (mg) & Kisaran/range & 3 & 15 \\
Laktosa (mg) & Kisaran/range & 67 & 79 \\
DE60 (\%) & Maksimal & 65,78 & 79,39 \\
Kekerasan (kg) & Kisaran/range & 4 & 7,1 \\
Kerapuhan (\%) & Minimal & 0,06 & 0,67 \\
Waktu hancur (menit) & Minimal & 6,22 & 8,14 \\
\hline
\end{tabular}

Waktu hancur

Model linear digunakan untuk menjelaskan hubungan jumlah crospovidone terhadap waktu hancur dan diperoleh nilai $\mathrm{p}$ value model 0.0033. hal tersebut memiliki makna bahwa adanya perbedaan jumlah crospovidone, memiliki pengaruh yang bermakna terhadap nilai waktu hancur observasi. Hubungan antara perbedaan jumlah dan respon tersebut dapat dilihat berdasarkan persamaan respon waktu hancur dan contour plot (gambar 1).

Disolusi efisiensi hingga menit ke-60 (DE60)

Disolusi efisiensi merupakan metode untuk menggambarkan kurva disolusi menjadi lebih sederhana karena dengan satu ekspresi dapat menggambarkan semua titik dalam kurva disolusi sehingga dapat mempermudah membandingkan hasil disolusi banyak formula. Dari hasil p-value model (linear) diperoleh nilai 0,7973 . Nilai model $>0,05$ menunjukkan bahwa tidak terdapat pengaruh yang signifikan antara formula yang direkomendasikan oleh Design Expert terhadap hasil persen disolusi efisiensi obsevasi. Hal tersebut mengandung arti bahwa perbedaan jumlah crospovidone pada tablet tidak berpengaruh terhadap hasil disolusi levofloksasin.

\section{Penentuan Formula Optimal}

Tabel III menyajikan komponen respon dan target respon untuk mendapatkan formula opimal.

Berdasarkan komponen pada tabel III, didapatkan formula optimal dengan nilai desirability 0,546, yaitu formula dengan jumlah crospovidone maksimal sebesar $15 \mathrm{mg}$ dan jumlah laktosa minimal sebesar $67 \mathrm{mg}$ dalam 1 tablet. Formula tersebut diuji kebenarannya dengan membuat kembali tablet dengan komposisi bahan rekomendasi dan dilakukan uji sifat fisik berupa kekerasan, kerapuhan, waktu hancur, dan $\mathrm{DE}_{60}$. Selanjutnya, nilai prediksi respon dan nilai observasi respon yang diperoleh dilakukan uji one sample t-test.

Dari hasil uji analisis dengan one sample t-test, nilai signifikansi $>0,05$ pada semua respon. Hal tersebut menunjukkan bahwa perangkat lunak Design Expert mampu menunjukkan hasil respon sifat tablet levofloksasin dengan disintegran crospovidone dengan benar. 
Tabel IV. Nilai prediksi dan observasi respon formula optimal

\begin{tabular}{lcc}
\hline Respon & Nilai prediksi & Nilai observasi \\
\hline DE60 $_{6} \%$ ) & 71,95 & 74,67 \\
& & 77,34 \\
Kekerasan (kg) & 4,00 & 73,01 \\
& & 4,0 \\
& & 4,0 \\
& & 4,1 \\
Kerapuhan (\%) & 4,6 \\
& \multirow{2}{*}{0,42} & 4,3 \\
Waktu hancur (menit) & & 4,4 \\
& \multirow{2}{*}{6,44} & 0,33 \\
& & 0,5 \\
& & 0,49 \\
& & 6,36 \\
\end{tabular}

\section{KESIMPULAN}

Formula optimal yang didapatkan adalah formula dengan jumlah crospovidone $10 \%$ ditandai dengan nilai desirability 0,55 menghasilkan sifat fisik tablet berupa rata-rata kekerasan 4,33 kg, kerapuhan 0,49\%, waktu hancur 6,36 menit, dan rata rata $\mathrm{DE}_{60}$ sebesar $75,00 \%$.

\section{UCAPAN TERIMA KASIH}

Pada penelitian ini Antibiotik MRSA yang digunakan kepada pasien dengan kesesuaian berupa jenis, dosis, frekuensi, dan durasi antibiotik sebanyak 6 kasus yang sesuai berdasarkan Guideline Kemenkes, IDSA, dan John Hopkin dan 68 kasus dinyatakan tidak sesuai. Tidak terdapat hubungan positif antara kesesuaian antibiotik definitif berdasarkan Guideline terhadap clinical outcome pasien, secara statistik $(p>0,05)$.

\section{DAFTAR PUSTAKA}

Departemen Kesehatan Republik Indonesia, 2014. Farmakope Indonesia Edisi V. Kementerian Kesehatan Republik Indonesia.

Desai, V., Afieroho, O., Dagunduro, B., Okonkwo, T., Ndu, C., 2011. A Simple UV Spectrophotometric Method for the Determination of Levofloxacin in Dosage Formulations. Trop. J. Pharm. Res. 10.

Gerber, W., Hamman, J.H., Steyn, J.D., 2018. Excipient-drug pharmacokinetic interactions: Effect of disintegrants on efflux across excised pig intestinal tissues. J. Food Drug Anal. 26, S115-S124.

ICH, 2017. Annex 9(R1) Tablet Friability General Chapter Guidance for Industry. US Dep. Health Hum. Serv. Food Drug Adm. 6.

Khan, K.A., 1975. The concept of dissolution efficiency. J. Pharm. Pharmacol. 27, 4849.

Mohanachandran, P.S., Sindhumol, P.G., Kiran, T.S., 2011. Superdisintegrants: An Overview. Int. J. Pharm. Sci. Rev. Res. 6, 5.

Noel, G.J., 2009. A review of levofloxacin for the treatment of bacterial infections. Clin. Med. Ther. 1, CMT-S28.

Pabari, R.M., Ramtoola, Z., 2012. Effect of a Disintegration Mechanism on Wetting, Water Absorption, and Disintegration Time of Orodispersible Tablets. J. Young Pharm. 4, 157-163.

Politis, S., Colombo, P., Colombo, G., M. Rekkas, D., 2017. Design of Experiments (doe) in Pharmaceutical Development. Drug Dev. Ind. Pharm. 43, 889-901.

Sastry, S.V., Nyshadham, J.R., Fix, J.A., 2000. Recent technological advances in oral drug delivery - a review. Pharm. Sci. Technol. Today 3, 138-145.

Thakkar, H., Desai, J., 2015. Influence of excipients on drug absorption via modulation of intestinal transporters activity. Asian J. Pharm. 9, 69.

United States Pharmacopeial, 2009. The United states Pharmacopeia 32 and The National Formulary 27 (USP-NF). USA. 